\title{
How can the Reformation's focus on faithfulness to Scripture inspire us for mission?
}

\begin{tabular}{|c|c|}
\hline $\begin{array}{l}\text { Author: } \\
\text { Kirk J. Franklin }\end{array}$ & \\
\hline $\begin{array}{l}\text { Affiliation: } \\
\text { 1Department } \\
\text { Religion and } \\
\text { Faculty of The } \\
\text { University of } \\
\text { South Africa }\end{array}$ & $\begin{array}{l}\text { f Science of } \\
\text { hissiology, } \\
\text { ology, } \\
\text { retoria, }\end{array}$ \\
\hline $\begin{array}{l}\text { Research Proj } \\
\text { Project Leader } \\
\text { Project Numb }\end{array}$ & $\begin{array}{l}\text { ect Registration: } \\
\text { : N. Niemandt } \\
\text { er: } 04317734\end{array}$ \\
\hline $\begin{array}{l}\text { Description: } \\
\text { Dr Franklin is } \\
\text { in the researc } \\
\text { 'Ecodomy', dir } \\
\text { Prof. Dr Nelus } \\
\text { Department o } \\
\text { Religion and } \\
\text { Faculty of The } \\
\text { University of }\end{array}$ & $\begin{array}{l}\text { participating } \\
\text { project, } \\
\text { ected by } \\
\text { Niemandt, } \\
\text { f Science of } \\
\text { Missiology, } \\
\text { ology, } \\
\text { retoria. }\end{array}$ \\
\hline $\begin{array}{l}\text { Correspondin } \\
\text { Kirk Franklin, } \\
\text { kirkfranklin31 }\end{array}$ & $\begin{array}{l}\text { g author: } \\
\text { @gmail.com }\end{array}$ \\
\hline $\begin{array}{l}\text { Dates: } \\
\text { Received: } 21 \mathrm{~S} \\
\text { Accepted: } 02 \\
\text { Published: } 14\end{array}$ & $\begin{array}{l}\text { ept. } 2017 \\
\text { Fec. } 2017 \\
\text { Feb. } 2018\end{array}$ \\
\hline $\begin{array}{l}\text { How to cite th } \\
\text { Franklin, K.J., } \\
\text { the Reformati } \\
\text { faithfulness to } \\
\text { inspire us for r } \\
\text { Teologiese Stu } \\
\text { Theological St } \\
\text { a4817. https:/ } \\
\text { 10.4102/hts.v }\end{array}$ & $\begin{array}{l}\text { is article: } \\
\text { 2018, 'How can } \\
\text { on's focus on } \\
\text { Scripture } \\
\text { nission?', HTS } \\
\text { dies/ } \\
\text { udies 74(1), } \\
\text { /doi.org/ } \\
\text { 74i1.4817 }\end{array}$ \\
\hline $\begin{array}{l}\text { Copyright: } \\
\text { (c) 2018. The A } \\
\text { Licensee: AOS } \\
\text { is licensed unc } \\
\text { Creative Comr } \\
\text { Attribution Lic }\end{array}$ & $\begin{array}{l}\text { Iuthors. } \\
\text { IS. This work } \\
\text { ler the } \\
\text { nons } \\
\text { ense. }\end{array}$ \\
\hline Read online: & \\
\hline 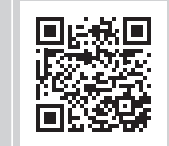 & $\begin{array}{l}\text { Scan this QR } \\
\text { code with your } \\
\text { smart phone or } \\
\text { mobile device } \\
\text { to read online. }\end{array}$ \\
\hline
\end{tabular}

Since the 16th century Protestant Reformation, the issue of divine inspiration and authority of the Bible has stood at the centre of Reformed faith. The question asked then, which is still with us, is whether the Bible is sufficient and complete as a revelation from God? Conflicts that arose during the Reformation still brew today, albeit with different players and contexts. Furthermore, how does the faithfulness to Scripture by reformers, such as William Tyndale and Martin Luther, and pre-Reformer, John Wycliffe, influence the church's involvement and influence in God's mission today?

\section{Introduction}

The recent 500th anniversary of the Protestant Reformation is an opportunity to explore a connection between faithfulness to Scripture and the inspiration for participating in God's mission. Placing a discussion within a historical context helps to fulfil theologian Alister McGrath's (2013:14) observation that studying 'history makes us alert to both the mistakes of the past and the alarming way in which they are repeated in the present'. Film director Woody Allen said something similar: 'History repeats itself. It has to; nobody listens the first time around'.

The Protestant Reformation's five pillars are well noted as sola Scriptura (Scripture alone), sola gratia [grace alone], sola fide [faith alone], solus Christus [Christ alone] and soli Deo gloria [glory to God alone] with 'sola fide - the doctrine of justification by faith alone' as the trigger for the Reformation (Barrett 2016:11).

A commitment lies behind sola fide and that is sola Scriptura - 'the affirmation that the Bible alone is the ultimate authority for life and doctrine' (Barrett 2016:13). It was the foundational principle of the Protestant Reformation. The doctrine of the authority of Scripture shaped the reformers and gave them 'the courage to separate with Rome in their proclamation of the gospel' (Barrett 2016:13).

Since the 16th century, the 'affirmation of the divine inspiration and authority of the Bible has stood at the centre of Reformed faith' (Barrett 2016:14). 'Sola Scriptura acknowledges that there are other important authorities for the Christian, authorities who should be listened to and followed. However, Scripture alone is our final authority' (Barrett 2016:23).

My objectives in this article are to explore (1) the translatability of the Bible; (2) how the Bible has been translated, including the work of John Wycliffe, Martin Luther and William Tyndale; (3) how their work serves as a framework for reformation; (4) Luther's faithfulness in mission; and (5) how faithfulness from the reformers shapes and influences participation in God's mission (the missio Dei) today.

\section{Incarnation and translatability of God's Word}

There are many grids through which we could explore themes from the Protestant Reformation. For example, we could take any of the five pillars as starting points. Because I have already noted the underlying importance of sola Scriptura to the reformers, let us start with a brief historical context of the availability of the Bible as a foundation for reform.

The translatability of God's Word is central to understanding God and his Word. Andrew Walls (1996:26) explains: 'Christian faith rests on a divine act of translation: "the Word became flesh, and dwelt among us" (Jn 1:14).' The incarnational Word has the inherent capacity 'to be articulated, received, appropriated, and reproduced into a potentially infinite number of cultural contexts' (Tennent 2010:325). The prior act of the incarnation of Christ demonstrates how 'God chose 
translation as his mode of action for the salvation of humanity' (Walls 1996:26). This gives us confidence in how the translatability of the Bible rests on the incarnation and therefore provides a mandate for why translation of the Bible into the languages of the world is important in the mission of God.

\section{The Old Testament into Greek}

The activity of translating the Bible, or at least portions of it, started with the Septuagint, the ancient translation of the Hebrew Old Testament into Koine Greek. (It was commonly known as the LXX - Roman numerals for 70 [plus two] because tradition suggests it was that number of Jewish leaders from Alexandria who produced it). The work started around 285 BCE. Eventually, it was the Jews of the Diaspora living in Alexandria who 'had abandoned the language of their fathers [and thought] that the only way to preserve the religious legacy of their ancestors was to translate it into the foreign language' (Marcos 2000:19). These Jews were bilingual and lived in 'the Greek world with a high proportion of Greek-speaking Jews who did not know the original language of the scriptures' (Marcos 2000:20), so their translation was carried out in order to address their liturgical and educational needs.

Once the Bible was translated, it was copied over and over by scribes and distributed widely around the Mediterranean area. It should be pointed out that the LXX was actually 'a collection of translations depending on the book [resulting in] a whole gamut of translation techniques which run from literal translation (including transliteration) to paraphrase' (Marcos 2000:23). It was from the Septuagint that Jesus himself quoted in the gospel accounts.

Those following traditional Judaism eventually abandoned the Septuagint and stated that the Torah could not be adapted into Greek. By then the Septuagint was largely in the hands of Hellenistic Gentile believers, and these Scriptures enjoyed a new function 'as they became an authoritative sourcebook for Greek Christians' who were shaping a new worldview as believers (Walls 1996:33).

\section{The New Testament}

It is worth remembering that the church existed before any of the New Testament was written. There are therefore accounts of churches that functioned for a long time without the written Bible. People did not have the literacy skills that could give them access to the translated text. In addition, there were also Christians who, for various reasons, could not own any portion of translated Scriptures. These situations serve as a reminder that the Holy Spirit is not limited to situations where everyone has their own copy of the translated book' (Smalley 1991:217).

The accounts about the life and teachings of Jesus were circulated orally from person to person. During 50-60 CE, the Apostle Paul's letters were either written in Koine Greek or dictated to scribes who transcribed them (Wegner 1999:207). These letters were read in the meetings of the early church. Scribes recopied them by hand, making them more readily available.

\section{The Bible in the early church}

In the early church, the Bible was considered the book for every Christian. The church fathers emphasised Bible reading, which in turn encouraged people to become literate. For those who were not literate, the Bible was read publicly, because it was central for deepening the spiritual life of the individual Christian and the church.

Jerome translated the Bible into Latin during 366-384 CE. His translation was 'based on the Hebrew text rather than the more acceptable Greek Septuagint [making it] controversial and divisive at the time' (Sanneh 2008:47). This was because the Septuagint was seen to be 'inspired and thus authoritative' (Wegner 1999:254). Many Old Latin texts of the Old Testament were in circulation prior to this. However, it was Jerome's scholarly work in the Vulgate (meaning 'common') that elevated this translation as the official one of the Western church. The Vulgate went through various revisions and became the official version of the Roman Catholic Church.

\section{John Wycliffe, William Tyndale and the English Bible}

In the Roman Catholic Church of the 14th century, the use of the Vulgate Bible was reserved for the clergy and used in the monasteries. In England, church leaders were reluctant to allow it to be translated into English because such an act threatened the church, and church authorities believed they 'would lose power over and revenue from the common people; and that commoners would misunderstand and corrupt the teachings of the Bible' (Wegner 1999:273). There were two men who were key figures in Bible translation John Wycliffe and William Tyndale, whom we explore more closely.

\section{John Wycliffe (mid 1320s-1384)}

Also known as Wyclif or Wickliffe, he was an Oxford academic who became undeterred by the church's official position. He inspired, instigated and supervised the translation of the Bible into English from the Vulgate. Wycliffe was a Roman Catholic theologian who was motivated by his concern about the corruption of the church and its leadership. The church authorities intentionally made the Vulgate inaccessible to the laity so that it was only 'the clergy, who were supposed to translate the text and teach people its contents' (Lutzer 2016:Loc 309). Wycliffe realised the church leadership was motivated to deny the laity access to the Bible for fear of discovering the enormous inconsistencies 'between the lifestyles of the bishops and clergy and those commended - and practiced - by Christ and the apostles' (McGrath 2001:19). 
Wycliffe became dissatisfied with this situation and believed that 'rather than looking to the pope or his emissaries, one just needed to study the Bible to learn all that was necessary for the Christian life' (Lutzer 2016:Loc 301). Wycliffe was adamant that if ordinary people had the Bible in their own English language, 'the few who were able to read could then read it to others, and the gospel could be rediscovered' (Lutzer 2016:Loc 309). However, the church was certain 'that if the common people read the Bible, they would conjure up all kinds of strange interpretations' (Lutzer 2016:Loc 320). Wycliffe was willing to take the risk, believing that even lay people did not need 'special interpretation ... to understand' (Connolly 1996:77). They might come to understand the gospel and be saved. So he wanted as many people as possible, whether clergy or laity, to have a chance to read the Bible for themselves (Lutzer 2016:Loc 320).

Wycliffe paid dearly for his criticism of the Roman Catholic Church: he was dismissed from the University of Oxford in 1381. The Lollards (members of a religious movement, from the mid-14th century to the English Reformation, initially led by Wycliffe) completed the translation after Wycliffe's death in 1384. It is probable that Wycliffe translated parts or most of the New Testament, though scholars note that it was not exactly the finest translation because it was translated from the Vulgate. However, even with such deficiencies, people had access to a more accurate reading of the New Testament than what they had been used to hearing from the clergy (Lutzer 2016:Loc 315). It was John Purvey who, after Wycliffe's death, revised the Bible translation from 1388 to 1395 (Drake 2008:66).

Unfortunately, Wycliffe's Bible was not widely accessible because the printing press had not yet been invented. All of Wycliffe's Bibles were copied by hand, and it was nearly another 100 years before Gutenberg invented his printing press. Prior to this, it usually took one scribe approximately 10 months to make one copy. Therefore, only the wealthy could afford to hire a scribe. Today, there are still about 250 copies of Wycliffe's Bible in existence, indicating its extensive distribution, even though there were all manner of attempts to confiscate and destroy his translation (Drake 2008:66). Clergy considered that any laity who owned a Wycliffe Bible at the time of its release, or memorised any portion of it, to be participating in an act of treason (Drake 2008:66).

Erwin Lutzer (2016:Loc 309) claims Wycliffe's greatest influence was to 'popularise' the availability and use of the Bible. Wycliffe, with the Lollards, through 'giving people the Bible and stirring discontent with the papacy', sewed seeds for much broader and 'more drastic reforms' (Lutzer 2016:Loc 339). Wycliffe's Bible also opened the door for the future proliferation of English translations.

\section{William Tyndale (1494-1536)}

He lived and worked among ordinary people. Although he was a highly skilled 'linguist and craftsman', he was never tempted to pursue higher places of employment and privilege (Daniell 1994:262). Tyndale was a scholar of Greek and Hebrew and wanted the King of England to understand how important it was for an entire 'cross section of the English population to have access to the Bible' (Ryken 2011:22). However, authorities prevented him from doing any translation in England, so he found refuge in Germany. There is some thought that Tyndale was influenced by Luther because the former translated the New Testament in a short time frame with similar vocabulary and style to Luther's German translation (McGrath 2001:70). Tyndale used the original languages of Greek and Hebrew and printed his work on Gutenberg's press. Consequently, he has been called 'the father of the English Bible' (Connolly 1996:140).

As with Wycliffe, the English Catholic Church's opposition to Tyndale's translation was certain. The authority of the priests rested solely on the church, and its authoritative hold on the laity was dependent upon biblical ignorance. Consequently, 'any free use of the Bible in worship and thought signalled a deep threat to this authority' (Drake 2008:63). The church hierarchy saw Tyndale's translation as bringing 'confusion and destruction rather than the edification of souls' (Duffy 2017:70).

The church banned the importation of Tyndale's Bible. Therefore, the printed copies of Tyndale's Bible had to be smuggled back into England. Because of his persistence in printing and shipping his Bibles into his home country, Tyndale was eventually tracked down and burned to death in 1536 by orders of the Bishop of London.

Through Tyndale's dedicated efforts, 'floodgates [were opened] that could no longer be closed' (McGrath 2001:88), and it was only a matter of time before English translations were printed and distributed in England without the dangers that Tyndale had suffered. English language translations that soon followed Tyndale's New Testament (1526) were Coverdale's Bible (1535), Matthew's Bible (1537), The Great Bible (1539), the Geneva Bible (1560) and the [Anglican] Bishop's Bible (1568).

Tyndale might have expected to be attacked, possibly physically, but certainly verbally, but he did not know who would lead that attack.

\section{Thomas More, the agitator}

It was Thomas More (1478-1535) who led the attack against Tyndale. More was one of the leaders within the Roman Catholic Church's Counter-Reformation (1545-1563), which sought to halt the spread of the Protestant movement within Western Europe. Thomas More was known to circulate in the 'wealthy, mutually flattering, small exclusive circle of English humanism' and the political elite (Daniell 1994:262). More warned English Catholic Church leaders about what would happen when ordinary people had access to the Bible in English: 
Men now could be harmed by their own perverse misreading even of [the very Scripture of God] and for that reason the King had forbidden the reading of the Bible in English, till men and times improved. (Duffy 2017:45)

More's conviction rested on his view that the Bible was only correctly understood in the hands of the church, its doctrine and the 'divinely inspired exegetical tradition' of the clergy (Duffy 2017:57). More played on the suspicion and mistrust between the church and Luther and Tyndale's followers, in order to pit them against each other in the debate about the Bible and the church (Duffy 2017:57).

More insisted that lay people were unable to comprehend the 'high secret mysteries of God' (Duffy 2017:69). He also anticipated that many clergy wanted to keep the Bible out of the hands of normal people to avoid paralysis and rebellion among them. More believed that biblical interpretation was a 'task for the Church's theologians and approved preachers' (Duffy 2017:69).

However, More was aware of the hold that the vernacular Bible had established even among many otherwise conservative laity in King Edward's reign and was conscious of the danger of appearing to suppress the Word of God (Duffy 2017:114). There was no reason to withhold an English Bible from the people, because the English language was suited to translation.

The powerful Cardinal Thomas Wosley supported More in his vindictive anti-Tyndale and Luther crusade (Daniell 1994:256). An example of More's theological attack on Tyndale was the latter's translation of ekklesia as 'congregation'. More found this offensive in his defence of 'the orthodox doctrine that the Church came first and Scripture followed' (Daniell 1994:276). More was adamant that it was impossible:

to understand the Bible without the guidance of the infallible Church [because] Scripture ... belongs to the Pope and the hierarchy of the Church. It is interpreted by the living voice of the Church. (p. 278)

Tyndale objected to the church's doctrine of the 'secret, oral tradition handed down by the Apostles' to the clergy as being more important than the Scriptures (Daniell 1994:255). Tyndale taught that the living voice of the Church is the congregation of believers' guided by the Holy Spirit, rather than a select group of clergy. The Bible can and should be interpreted and reinterpreted in every generation. This makes Tyndale modern and forward looking, 'releasing theology' to each generation of believers (Daniell 1994:278).

Both More (for his political stand against the King and Queen of England) and Tyndale (for his translation work) died as martyrs, close in time to each other. They were, intriguingly, saved from extreme torture: 'More was not disembowelled' and Tyndale was strangled before being burnt to death (Daniell 1994). However, their legacies were total opposites:
More gave us three quarters of a million words of scarcely readable prose attacking Tyndale. Tyndale outraged More by giving us the Bible in English -England's greatest contribution to the world for nearly five hundred years. (p. 280)

It is worth noting that even the English Catholic Jerusalem Bible relies significantly on Tyndale's 'legacy of translation' (Daniell 1994:262).

\section{Martin Luther and the German Bible}

By the end of the 16th century, events were to change the religious nature of most of Europe. The changes began with Luther's 95 Theses affecting Germany and northern Europe, and continued with Tyndale's Bible, influencing the Englishspeaking world (Daniell 1994:278).

Martin Luther (1483-1546) believed the work of translating the Bible into German was too important to be left to someone other than himself because the majority of the laity could not read Latin, the language of learning. Luther had resolved to put the Bible into a form of German so natural and so forceful that it would speak to the hearts of all Germans. He wanted the Scriptures to be translated accurately into the language they used in their everyday lives. The layperson's access to the Bible was as much about coping with the institutional church's political power over their lives as it was about developing personal spirituality (McGrath 2001:53).

Friedrich the Wise had arranged for Luther's escape to Wartburg Castle. Exiled and hiding from the Roman Catholic hierarchy, Luther wasted no effort in the use of his time. His diligence allowed the Greek New Testament to be translated into German in 10-11 weeks in 1522, with ongoing revisions following (Barrett 2016:51). It was later in 1534 that the whole Bible became available.

Luther's efforts meant that for the commoner, thousands could now read the Scriptures in their own language for the first time. They heard God's Word 'thunder from the pulpit in their heart language' (Steele 2016:11). Luther's work had such wide influence that at the time of his death in 1546, there were at least half a million copies of the German Bible in circulation (Barrett 2016:51).

Luther's translation work was far from harmless. Matthew Barrett (2016:51) notes that Luther 'knew [his work] could be a cannonball blowing a hole right through the wall of the infallible authority of the pope'. Pere Simon, a Roman Catholic contemporary of Luther, noted that Luther was the first to venture into translating the Bible into the 'vulgar [German] tongue from the Hebrew text' (Luther \& Chalmers 1857:xc). Simon also observed that Luther was the first to courageously undertake to 'reform an overgrown system of idolatry and superstition by the pure word of God' (Luther \& Chalmers 1857:xc). Luther also challenged the papal decree on indulgences, stating only the Scriptures, not the church or pope, could 'establish articles of faith' (Lutzer 2016:Loc 889). According to Arnold (1999:np), the selling of indulgences in the Middle Ages church took place when: 
priests employed their special rapport with God to perform certain religious acts for laymen. For a price, Clergy would pray, fast and read scripture for a person. In other words, priestly services were bought. This was later developed into buying up time one might have to spend in purgatory.

Luther had come to his theological convictions much earlier, and let them be known through his 'vitriolic, bombastic, and sarcastic diatribe[s] against the pope' (Lutzer 2016:Loc 1182). Consequently, in 1519, at Leipzig, Luther was invited into a theological examination with highly respected Johann Eck, defender of Roman Catholic doctrine. The challenge Eck presented to Luther was a debate on the authority of the church versus the Scriptures. Luther reiterated his position that 'pontiffs can err, and that others have the right to interpret Scripture' (Lutzer 2016:Loc 885). Luther never hesitated in using the 'mighty sword of God's Word like a battering ram, which infuriated [the pope] and served to strengthen the resolve of God's people' (Steele 2016:6). Luther stated that 'a simple layman armed with Scripture is to be believed above a pope or council without it' (Lutzer 2016:Loc 889). However, the church saw Scripture and tradition as equally inerrant in authority (Barrett 2016:26).

In his attempts at simple preaching and clear writing, Luther wanted to persuade people that, given a chance, the Word of God would transform one's thinking and, as a result, that any part of the 'rotten old structures [of the Roman Catholic Church] would collapse' (Steele 2016:12). Luther sought to challenge the obvious, that the educated clergy and laity in the Roman Catholic Church had no faith that the average person could understand Scripture well, because the people did not understand Latin like the educated clergy. Also, the authorities did not think the average person could interpret Scripture faithfully. The heart of Luther's debate with the church was about authority - did it rest with the Scriptures or with the pope? (Lutzer 2016:Loc 908). For Luther, there was no question, only the Scriptures gave 'supreme authority' (Lutzer 2016:Loc 914). Luther did not set out to replace the Roman Catholic Church and start his own. He took exception to those who would proudly say that they were 'Lutherans', because he wanted them to be followers of Christ alone. Therefore, in a sense, Luther was a faithful member of the institutional church, even though this church rejected him and his views.

In a time of vast illiteracy in late medieval Europe, reformers like Luther assumed that as the Word of God grew in people's hearts, they became transformed by God's Spirit. By the time of the Reformation, more and more people were learning how to read. They wanted access to the most important book, the Bible. As a result, the 'Reformation tides continued to swell' (Steele 2016:12), and like a pebble thrown into a pool of water, Luther's position created ripples that went wider and wider throughout the church (Lutzer 2016:Loc 914). The Scriptures are the source of our reformation because the Scriptures point us to the One who will transform our lives. Individual Christians make up the body of Christ, the church. Therefore, the church remains absolutely necessary for the spread of the gospel and for mission.
Luther's work advanced the Protestant Reformation in many ways, but three are significant: (1) challenging the Roman Catholic Church's doctrine of salvation as merited through 'faith in the church and good works prescribed by the church [such as] external actions, legal observance and penitential works' (Arnold 1999:n.p.) rather than an undeserved gift of grace from God; (2) the empowerment of the laity over an exclusive and controlling clergy (Lutzer 2016:Loc 1084); and (3) reforms and renewal brought to the church through the accessibility of the Bible to the laity (McGrath 2001:55).

\section{Translation efforts for the Counter- Reformation}

The Roman Catholic Church's Counter-Reformation was led by its 'upper-class clergy and papacy [that] brought renewal and reform in the church and an external reaction in opposition to Protestantism' (Cairns 1996:337) and contained the spread of the Protestant movement to within Western Europe.

William Allen (1532-1594), an English Catholic Church cardinal, was very aware of how the English Bible was critical in the success of the English Protestant Reformation. He resolved to remove any gain this gave the Protestants (Duffy 2017:148). It followed that Gregory Martin's translation of the New Testament (1582) helped this cause in what later became known as the Rheims-Douay Bible for the Catholic Church. Martin and Allen's purpose was to support English Catholics in the Counter-Reformation. Martin consulted the Hebrew, Greek and Latin texts and Tudor Protestant Bible versions. Even though Martin disdained these heretical Protestant mistranslations, this 'did not prevent him from borrowing liberally from Tyndale and his successors' (Duffy 2017:176).

Martin's careful work produced a consistently literal translation, and his practice of 'translating the same Hebrew or Greek word by the same English equivalent ... gave him a decided polemical [or opinionated political] edge on his Protestant opponents' (Duffy 2017:177). The release of Martin's New Testament was a momentous event for the Counter-Reformation because Catholic Bible translations were rare and likely to bring suspicion of heretical leanings of the translators (Duffy 2017:178).

\section{Ideological influences after the Protestant Reformation}

During the Age of Enlightenment (1650+), its philosophers, such as Immanuel Kant, René Descartes and John Locke, raised a series of questions that confronted Western culture and ultimately questioned the idea of truth. The outcome was the 'imposition of the scientific model of rationality upon all truth' with the claim that it was only scientific data that could be 'objectively understood, objectively defined, and objectively defended' (Barrett 2016:13). Consequently, modernism made no provision for the idea of 'special revelation and openly attacked the possibility of supernatural intervention in world history' (Barrett 2016:13). 
Meanwhile, around 1870 in the United States, a form of philosophy emerged called 'pragmatism', postulating that truth comes from social discussion, and the truthfulness of ideas is determined by whether they meet needs of contemporary American society (Barrett 2016:14). It employs 'thought as a weapon to enable more effective action' (West 1989:5). It therefore opposes the notion of the 'ultimate authority and truthfulness of Scripture' (Barrett 2016:14).

Enlightenment and modernity (19th century) merged into postmodernity, perhaps nothing more than 'the logical extension of modernism in a new mood' (Barrett 2016:14). Postmodernists claim that all concepts of truth are social constructs and any claims to truth itself have to be rejected. Not long ago, Oxford Living Dictionaries announced their Word of the Year as 'post-truth' (popularised as 'fake news'), which they defined as how 'objective facts are less influential in shaping public opinion than appeals to emotion and personal belief'. On the political front in the United States and the United Kingdom, we have seen the rise of public and political figures and the media that know how to use posttruth or alternative facts to their advantage. All purveyors of truth - religious, philosophical, political and cultural leaders - must be questioned, with the aim of establishing a new authority. It is no longer the authority of established institutions, religions and philosophy itself, but to the person him or herself. Truth is made to become subjective. If there is still usefulness in sources of truth such as the Scriptures, these can be upheld, but if they are deemed no longer useful, they can also be set aside. An outcome, something that Rome would never have considered in the 16th century, is that the 'inspiration and inerrancy of Scripture [is easily] abandoned' (Barrett 2016:22).

\section{Luther's faithfulness in God's mission}

Luther realised he needed 'to die to his own efforts' to achieve salvation and accept the unmerited favour of God. As he poured all of his efforts into reading and understanding the Bible, Luther found answers that his 'soul longed for' (Lutzer 2016:Loc 775).

Luther had to settle for himself 'if the Bible alone was an infallible guide for matters of faith and practice' (Lutzer 2016:Loc 831). The growing conflicts between him and the church hierarchy forced him to the conclusion that it was. Armed with this conviction, Luther (2016) challenged the:

traditions of the church that had been evolving for centuries. It was the book that enabled him to understand the gospel [and it] was the book that would enable him to defend it. (Loc 826)

Luther believed in the power of God's unfailing Word and that 'the gates of hell would not prevail against it'. He found comfort from God's assurance of protection, provided that he remained 'stout and steadfast' in the Word (Luther \& Chalmers 1857:13). Luther stated that the one who 'believes God's Word overcomes all, and remains secure ... against all misfortunes [and] fears nothing, neither hell nor the devil'
(Luther \& Chalmers 1857:19). He believed one should not 'criticise, explain, or judge the Scriptures by ... mere reason' (Luther \& Chalmers 1857:2). Instead, Luther advised, through diligence in prayer and meditation, one search the Scriptures to find God's truth (Luther \& Chalmers 1857:3).

Luther stated that one of the greatest tragedies for Christians throughout time was the 'calamity' of having 'God's word taken from them, or falsified, so that they no longer have it pure and clear' (Luther \& Chalmers 1857:6).

Luther stated that the condemnation of God's Word surpasses 'all other plagues in the world' and for which there will be punishments, 'eternal and corporal', for all who are guilty of such acts (Luther \& Chalmers 1857:14).

Luther believed in the eternal characteristic of God's Word, in contrast to the word of humans that have 'a little sound, that [fly] into the air, and soon' disappear (Luther \& Chalmers 1857:21). He felt this was why one must 'diligently study God's Word, and know and assuredly believe that God himself speaks' to us just as he spoke to those in the Scriptures. Luther noted the example of David of the Old Testament who experienced 'gladness [but often] mixed up with sorrow and pain [and] underwent manifold trials and tribulations' associated with the murder and adultery he had committed. This was 'no honeymoon for him, when he was hunted from one place to another', all while full of the fear of the Lord (Luther \& Chalmers 1857:21).

Luther spoke out against the formalism and institutionalism of the church. He used Christ's ministry of the gospel to the poor as a framework to challenge the 'unprofitable, lazy, ungodly people in monasteries' who could not spare a dollar for a teacher of the gospel. He said, 'superstition, idolatry, and hypocrisy, have ample wages, but truth goes a begging' (Luther \& Chalmers 1857:25).

Although in the isolation of his room in Wartburg Castle, and intensely focussing on translating the New Testament in a very short time frame, Luther 'had one of the most productive periods of his life' (Lutzer 2016:Loc 1347). It was a time of confronting his dark nights of the soul and of battling his doubts, depression and confusion while in a state of insomnia.

Luther understood the spiritual nature of his calling, and this meant encountering Satan's opposition. Luther (2016) said:

I can tell you in this idle solitude there are a thousand battles with Satan. It is much easier to fight against the incarnate Devil - that is, against men - than against spiritual wickedness in the heavenly places. Often I fall and am lifted again by God's right hand. (Loc 1353)

Even while facing persecution, Luther unwaveringly saw to the task of translating God's Word into the German vernacular so believers 'could read it for themselves and see the gospel truths that had so transformed his own life' (Barrett 2016:51). Through this responsibility, Luther sent a profound 'message 
to the German people that the Bible holds supremacy over all human traditions' (Barrett 2016:52).

Luther knew that his contemporary John Hus was burned at the stake, and so Luther assumed his would be the same fate (however, he died of physical illness and exhaustion). Clergy loyalists to the pope ensured that Luther's books were burned in cities like Cologne and Erfurt. In spite of this, 'Luther was winning the hearts' of the public (Lutzer 2016:Loc 1195).

\section{Considering faithfulness to God's mission}

What implications for mission can we draw from the Protestant Reformation's deep desire to see the church reflect the primacy of the Scriptures as it attempts to remain faithful in God's mission?

\section{The movement of joy of the Holy Spirit}

In its missional journey, the early church was 'thrust ... outward into [an] "explosion of joy"' (Tennent 2010:99). Luther experienced a similar joy in his discovery of the Scriptures and its revelation of God's gracious gift of salvation.

Throughout mission history, Kirsteen Kim (2009:47-48) notes that the Holy Spirit is already active in mission because 'the Christian faith is not imported but emerges out of local experience' because the Spirit brings 'local interpretation' into each context. The Holy Spirit is always seeking to 'transform all life-destroying values and systems' wherever they are (Keum 2013:13). Such transformation, according to Sung-wook Hong (2008:33), takes place 'through the encounter of the gospel with ... the power of the Holy Spirit'. The reformers encourage us to develop a missional spirituality through learning to discern the work of the Holy Spirit, discovering what God is doing in the world and joyfully joining with him.

\section{The Word of God challenges church traditions and structures}

Luther's work challenged the church's emphasis of salvation through works, the exclusive control by the hierarchy and the inaccessibility of the Bible by the laity. One could say that Luther rescued the gospel from the 'misleading traditions of medieval Christianity' (Lutzer 2016:Loc 226). Luther's zealous work that challenged one church tradition after another freed the gospel 'from centuries of encrusted traditions' and instigated the collapse of structures of the medieval church (Lutzer 2016:Loc 923).

Five hundred years later, it is possible to find structural forms of the church that have survived without the gospel transforming its people. There may also be spiritually powerless forms of Christianity prevalent. Therefore, we too must commit to defend and sometimes rescue the integrity of the gospel.

\section{The Bible needs to be available to all}

Throughout history, missionary activity has included the use of the vernacular. Luther, Wycliffe and Tyndale proved this. The particular language, whether German or English, was not a means to an end but, as Lamin Sanneh (1993:142) points out, was 'endowed with divine significance, so that [it could] substitute completely for the language of revelation'.

A primary issue of Bible translation concerns the language of the heart. This is the language that most effectively communicates to personal and deep spiritual matters for the majority of people in a given ethno-linguistic group. Kwame Bediako (2004:58) states, 'whenever Western missionaries ... made the Scriptures available to an African people in that people's own language, they weakened any Western bias in their presentation of the Gospel.' The consequence being that African Christians 'could truly claim they were hearing God speak to them in their own language. It amounts to the awareness that God speaks our language too.'

Luther, Tyndale and Wycliffe gave substantial effort to address Bible translation needs in German and English. Five hundred years later, Bible translation is still needed in approximately 1800 languages. Since the Protestant Reformation, the Scriptures have been translated into over 3223 languages, mostly in the last 150 years (Wycliffe. net 2017). Missionary activity has been 'the impulse behind the creation of more dictionaries and grammars of the world's languages than any other force in history' (Sanneh 2003:69). This indicates the significance of indigenous cultures and the worth of their languages and has aided their cultural preservation, as all people of all languages are created in the image of God.

The reformers supported the conviction that the translation of the Bible into the languages of the world is an indispensable foundation for the sustainable mission of God. This is not without challenge. Andrew Walls (1996:26) notes how 'translation is the art of the impossible' because of the risky complexity of transmitting meaning from 'one linguistic medium to another'. Rolland Allen, missionary to China in the early 20th century, was asked what needed to be done if the gospel was to be truly communicated. His response included an assumption of Bible translation:

There must be a congregation furnished with the Bible, the sacraments, and the apostolic ministry. When these conditions are fulfilled, the missionary has done [their] job; the young church is free to learn ... how to embody the gospel in its own culture. (Newbigin 1989:147)

Each member of the body of Christ, the church, needs to continually examine the Scriptures on a daily basis to test whether or not we are being faithful to Christ - including both his truth and mission - in our faith and practice. The Reformation stands as a singular historical event that in a sense is never supposed to end. Theologian Karl Barth, in 1947, derived a Latin phrase (reportedly from St Augustine): Ecclesia semper reformanda est, meaning 'the church must 
always be reformed' - the church must continually reexamine itself in order to maintain its purity of doctrine and practice. Leo Koffeman (2015) notes:

the Word of God, that is, God's self-revelation, is the foundation of the church; therefore, the church can be called creatura Verbi, created by the Word of God ... Any form of church renewal - or, for that matter, Reformation - should be based on this principle. (p. 2)

\section{The Bible needs to be read and used}

The positive effect of Bible translation in the vernaculars of Africa is attributed to how the Christian message is so readily translatable. This is because of its "refusal of a "sacred" language [and It] developed a "vernacular" faith' (Bediako 2004:32). This is in sharp contrast with other world religions that do not make such a claim.

The Bible is read in a radically different manner in the global South (or majority world) because it 'speaks to everyday realworld issues of poverty and debt, famine and urban crisis, racial and gender oppression, and state brutality and persecution' (Jenkins 2006:68). In this way, the 'Southern' Bible, as Jenkins (2006:68) calls it, 'carries a freshness and authenticity that adds vastly to its credibility as an authoritative source and as a guide for daily living'. Such cultures more easily identify with the Bible as being just for them. In some African contexts, Christians have been enthusiastic about the obvious cultural parallels that exist between their own societies and those of the Hebrew Bible, especially in the world of the patriarchs' (Jenkins 2006:68). Even though people in more modern African society may not have direct experience of their traditional cultures of nomadism or polygamy, they are still able to identify with 'the kind of society in which such practices were commonplace' (Jenkins 2006:68).

During times of persecution of the church and heresy within the church, those who have access to the vernacular Bible and understand it are better equipped to remain resilient in their Christian faith. However, churches without Scripture in local languages, 'even those at centres of Christianity like Alexandria, have disappeared from the map' (Hill 2006:82). Earlier in Europe, there was an emphasis on mother tongue Scriptures in the Protestant Reformation, and the church grew. But when the mother tongue Scriptures were neglected during the early Middle Ages, it was a time of spiritual decline for the church.

Christians in the West and growing urban contexts of the global South face the challenge of secularism, consumerism and the relativism of postmodernity. In such climates, the church and its theologians are forced to confront and address faith in a time of doubt. This is our daunting responsibility because people in secular contexts view the Bible with complacency and disdain, considering it to be an ancient book for societies that no longer exist, and that it promotes laws of morality that are irrelevant to postmodern societies.

\section{Sola Scriptura is no guarantee for unity}

Mark Noll (2017:np) notes the tension between blessing and chaos of sola Scriptura being played out today. He observes that Mongolia:

had virtually no Christian presence up to World War II, and even the decades following. But then John Gibbons and his Mongolian wife began translating the New Testament in 1972. When the communist government collapsed and Christians were able to go into Mongolia, they came in and used their translation. But then Bible wars began in the 1990s, when different groups argued about how to best translate certain words, like the one for God. Within 15 years, there were at least six or seven Protestantsponsored versions of the New Testament circulating, with antagonism between groups. So there it is. Protestantism at its finest. Chaos and discord.

Even so, Noll (2017:np) notes that today thousands of Mongolians worship Christ in churches 'with these competing Bible translations'. This arose 'because the Bible was opened for them'. While it also led to 'arguments among Mongolian Protestants, the message of Scripture - of new life in Christ - had exposure in Mongolia that it had not had during the coercive years of communism'. There are hundreds of churches today full of younger people. Noll concludes, 'there is a degree of chaos in relying on Scripture, but remarkable coherence as different groups respond to the Bible's message of new life in Christ.'

The Reformation opened the floodgates in Protestant churches to the ongoing proliferation of new groups being born out of older established groups. Luther was renowned for his vitriolic and argumentative positions. In some parts of the world, Lutherans and Roman Catholics are celebrating the 500th anniversary of the Reformation together even though they remain with significant differences.

Men and women can cause disunity through their use of Scripture. Yet, Jesus prayed for the church to be one (Jn 17). Unity, according to Jesus, is vital missionally so the world may know that the Father sent the Son. There will inevitably be conflicts and divisions among Christians. What is harder is to make a priority in finding ways of striving for unity.

\section{A challenge: Becoming bold reformers}

In this article, we have noted the influence of John Wycliffe as a pre-reformer and William Tyndale and Martin Luther as reformers. In particular, we explored their conviction that the laity needed to have access to the Bible in an understandable form. We have connected these reformers' faithfulness to their conviction to a contemporary challenge of our being faithful to God's mission today.

Martin Luther challenged the church and its centuries of tradition. His study of the Bible enabled him to understand the gospel. Luther discovered how the Scriptures in the vernacular enabled people to understand spiritual truths about God and his will for them. Through access to the sacred 
text, individuals and the Christian community take responsibility for their growth and nurture. They are 'no longer bound by what others say, they can develop their own theology and apply it to daily living' (Moreau 2000:125).

The Reformation position of sola Scriptura is still important today. The reformers stood up to the church clergy who 'had elevated tradition and its magisterium [institutional authority] to the level of Scripture' (Barrett 2016:21). Through the 'doctrine of the inspiration and authority of Scripture' passed on to us by the reformers, we too may have full confidence in God's Word despite the philosophical and theological problems of our times (Barrett 2016:14).

Our challenge is to become bold reformers who engage in the theological landscape, which is 'drowning in compromise and capitulation' (Steele 2016:13). Our further challenge must be to hold theological conviction with moral integrity, to be above criticism and willingly accountable, and not compromise the truth. We depend upon the power of the Holy Spirit. We find comfort in the sovereignty of God. We have joy because of the gospel and resolve to proclaim and demonstrate it wholeheartedly.

The determination of Martin Luther and the reformers should fill us with new missional zeal to 'do the right things for the right reasons - all for the glory of God' (Steele 2016:158). But, let's not overlook the price of this journey. Should we not, 'serve the Lord with fear, and rejoice with trembling'? (Ps 2:11). As we do so, we discover just how God 'chooses the risky course of partnership' with us as his co-workers and friends (Balia \& Kim 2010:128).

\section{Acknowledgements Competing interests}

The author declares that he has no financial or personal relationships which may have inappropriately influenced him in writing this article.

\section{References}

Arnold, J.L., 1999, The Roman Catholic Church of the middle ages, viewed 19 August 2017, from http://www.thirdmill.org/newfiles/jac_arnold/CH.Arnold.RMT.1.html

Balia, D. \& Kim, K. (eds.), 2010, Edinburgh 2010 Volume II: Witnessing to Christ Today, Regnum Books, Oxford

Barrett, M., 2016, God's word alone - The authority of scripture, Zondervan, Grand Rapids, MI.

Bediako, K., 2004, Jesus and the Gospel in Africa: History and experience, Orbis Books, Maryknoll, NY.
Cairns, E.E., 1996, Christianity through the centuries, 3rd edn., Zondervan, Grand Rapids, MI.

Connolly, W., 1996, The indestructible book, Baker Books, Grand Rapids, MI.

Daniell, D., 1994, William Tyndale: A biography, Yale University Press, New Haven, CT. Drake, D.L., 2008, A visual history of the English Bible, Baker Books, Grand Rapids, MI. Duffy, E., 2017, Reformation divided: Catholics, protestants and the conversion of England, Bloomsbury Publishing, London.

Hill, H., 2006, 'The vernacular treasure: A century of mother-tongue Bible translation', International Bulletin of Mission Research 30(2), 82-88. https://doi.org/10.1177/ 239693930603000208

Hong, S.W., 2008, Naming God in Korea: The case of protestant Christianity, Regnum, Oxford

Jenkins, P., 2006, 'Reading the Bible in the Global South', International Bulletin of Mission Research 30(2), 67-72. https://doi.org/10.1177/239693930603000204

Keum, J. (ed.), 2013, Together towards life: Mission and evangelism in changing landscapes, with a practical guide, WCC Publications, Geneva.

Kim, K., 2009, Joining with the spirit: Connecting World Church and Local Mission, Epworth, London.

Koffeman, L.J., 2015, "Ecclesia reformata semper reformanda" Church renewal from a reformed perspective', HTS Teologiese Studies/Theological Studies 71(3), Art. \#2875, 1-5. https://doi.org/10.4102/hts.v71i3.2875

Luther, M. \& Chalmers, A., 1857, Martin Luther's table talk, H.G. Bohn, London.

Lutzer, E., 2016, Rescuing the Gospel: The story and significance of the reformation, Kindle Edition, Baker Books, Grand Rapids, MI.

Marcos, F., 2000, The Septuagint in context: Introduction to the Greek version of the Bible, Society of Biblical Literature, Atlanta, GA.

McGrath, A., 2001, In the beginning: The story of the King James Bible and how it changed a Nation, a language and a culture, Doubleday, New York.

McGrath, A., 2013, Historical theology: An introduction to the history of Christian thought, 2nd edn., Wiley, Oxford.

Moreau, S. (ed.), 2000, Evangelical dictionary of world missions, Baker Books, Grand Rapids, Ml.

Newbigin, L., 1989, The Gospel in a pluralist society, William B. Eerdmans, Grand Rapids, MI.

Noll, M., 2017, 'The freedom and Chaos of Sola Scriptura: Historian Mark Noll helps unravel the uses and misuses of "the Bible alone"', interview by Mark Galli, May 26, 2017, Christianity Today, viewed 01 August 2017, from http://www. christianitytoday.com/ct/2017/june/freedom-and-chaos-of-sola-scriptura. html?start=1

Oxford Living Dictionaries, Word of the year 2016, viewed 14 August 2017, https:// en.oxforddictionaries.com/word-of-the-year/word-of-the-year-2016

Ryken, L., 2011, The ESV and the English Bible Legacy, Crossway, Wheaton, IL.

Sanneh, L., 1993, Encountering the west. Christianity and the global cultural process, Marshall Pickering, London.

Sanneh, L., 2003, Whose religion is Christianity? William B. Eerdmans, Grand Rapids, MI.

Sanneh, L., 2008, Disciples of all nations: Pillars of World Christianity, Oxford University Press, Grand Rapids, MI.

Smalley, W., 1991, Translation as mission: Bible translation in the modern missionary movement, Mercer University Press, Macon, GA.

Steele, D.S., 2016, Bold reformer: Celebrating the Gospel-Centered convictions of Martin Luther, Lucid Books, Houston, TX.

Tennent, T., 2010, Invitation to world missions: A Trinitarian missiology for the twentyfirst century, Kregel, Grand Rapids, MI.

Walls, A., 1996, The missionary movement in Christian history: Studies in the transmission of faith, Orbis Books, Maryknoll, NY.

Wegner, P., 1999, The journey from texts to translations: The origin and development of the Bible, Baker Academic, Grand Rapids, MI.

West, C., 1989, The American evasion of philosophy: A genealogy of pragmatism, Macmillan Press, London.

Wycliffe.net, 2017, Scripture and language statistics 2017, viewed 19 August 2017, from http://www.wycliffe.net/en/statistics 